Brit. F. vener. Dis. (1974) 50, 303

\title{
Doxycycline $\mathrm{HCl}$ (Vibramycin) syrup as a single-dose oral treatment for uncomplicated urethritis in men
}

\author{
C. B. S. SCHOFIELD AND G. MASTERTON \\ Department of Sexually-Transmitted Diseases, Greater Glasgow Health Board
}

Some years ago, Silvestre and Gallai (1968) successfully treated gonorrhoea in men using doxycycline $\mathrm{HCl}$ given in a single oral dose. In Glasgow comparable results were obtained in the treatment of gonorrhoea in women by Moffett, McGill, Masterton, and Schofield (1972), as well as in men by Masterton and Schofield (1972). Furthermore, a significant number of male patients who were suffering from non-specific urethritis were cured by this treatment.

At the same time, it was noted that, with doxycycline $\mathrm{HCl}$ in a dose of $300 \mathrm{mg}$., patients complained of gastrointestinal side-effects- 5 per cent. had nausea and 10 per cent. vomited. These side-effects were partly, but not completely, controlled by giving the capsules with milk.

In the present study, involving male patients suffering from uncomplicated urethritis, the same dosage of doxycycline $\mathrm{HCl}$ and the same protocol and criteria were used as in the previous trial, except that, in an attempt to eliminate the side-effects, a syrup instead of a capsule was used. The results obtained are compared with those of the previous trial.

\section{Methods}

266 male patients suffering from uncomplicated urethritis were admitted to the trial which covered a 10-week period starting in October, 1973. Irrespective of the microscopic diagnosis, the patients were given $30 \mathrm{ml}$. Vibramycin syrup $(50 \mathrm{mg} . / 5 \mathrm{ml}$.) in a single oral dose in the clinic. No other treatment was given, and patients with complicated infections, those in transit, and those who had previously been unreliable attenders were excluded from the survey.

227 (85.3 per cent.) were born in the United Kingdom. 32.7 per cent. were married, 57.5 per cent. were single, and 9.8 per cent. separated or divorced.

Received for publication November 20, 1973

Address for reprints: 67 Black Street, Glasgow G4 OEF

\section{Diagnosis}

A provisional diagnosis was made by the examination of Gram-stained urethral smears. The finding of $N$. gonorrhoeae in 144 cases was later confirmed by culture and the minimum inhibitory concentration (MIC) of penicillin $G$ for each strain was estimated by a diffusion method. The penicillin sensitivities of the strains are compared with those of the previous trial in Table I. There was little change in the incidence of less sensitive strains, defined as those requiring at least $0.1 \mathrm{\mu g}$. $/ \mathrm{ml}$. penicillin $\mathrm{G}$. This was 18.6 per cent. in the first trial and 18.8 per cent. in the present one, but there does appear to be some evidence of polarization. The incidence of the most sensitive strains, those with an MIC of $0.03 \mu \mathrm{g} . / \mathrm{ml}$. or less, has risen from 63.6 to 68.7 per cent., while the incidence of strains requiring an MIC of $0.3 \mu \mathrm{g} . / \mathrm{ml}$. or more, has risen from $5 \cdot 6$ to $15 \cdot 3$ per cent.

TABLE I Initial penicillin sensitivities of the infecting gonococci in the two studies

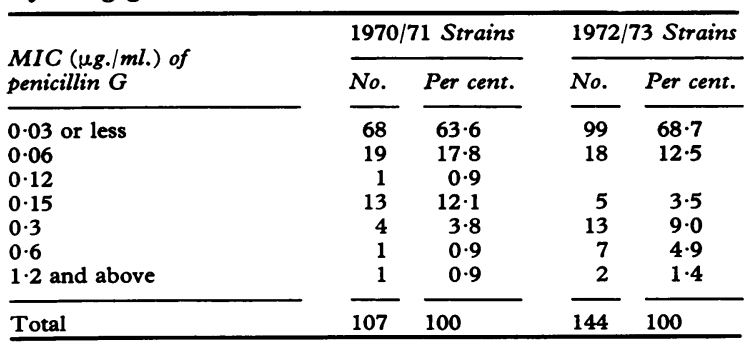

The sensitivity to other antibacterial agents was determined by disc sensitivity tests at the following doses: sulphafurazole $100 \mu \mathrm{g}$., erythromycin $10 \mu \mathrm{g}$., tetracycline $5 \mu \mathrm{g}$., kanamycin $30 \mu \mathrm{g}$., streptomycin $10 \mu \mathrm{g}$., and doxycycline $10 \mu \mathrm{g}$.

25 strains were resistant to streptomycin and ten to sulphafurazole. Two strains showed resistance to tetracycline and none to doxycycline. These and the number of resistant strains in the previous trial are shown in Table II (overleaf).

Between the two trials, the dose of the tetracycline disc was reduced from 10 to $5 \mu \mathrm{g}$. and this may account 
TABLE II Resistance of gonococci to other antibacterial agents in the two studies

\begin{tabular}{|c|c|c|c|c|}
\hline \multirow{2}{*}{$\begin{array}{l}\text { Antibacterial } \\
\text { agent }\end{array}$} & \multicolumn{2}{|c|}{ 1970/71 Strains } & \multicolumn{2}{|c|}{ 1972/73 Strains } \\
\hline & $\begin{array}{l}\text { No. } \\
\text { resistant }\end{array}$ & Per cent. & $\begin{array}{l}\text { No. } \\
\text { resistant }\end{array}$ & Per cent. \\
\hline Streptomycin & 21 & $19 \cdot 6$ & 25 & $17 \cdot 4$ \\
\hline Sulphafurazole & 8 & $7 \cdot 5$ & 10 & 6.9 \\
\hline Tetracyclines & 0 & - & 2 & $1 \cdot 4$ \\
\hline
\end{tabular}

for the two strains reported as resistant to tetracycline as in both cases the patients were cured.

Non-specific urethritis was diagnosed in the remaining 122 patients after examination of the urethral smears and cultures which excluded $N$. gonorrhoeae, $T$. vaginalis, and $C$. albicans.

\section{Results}

Routine post-treatment examinations were planned for the 2nd, 4th or 5th, 8th, 15th, 22nd, and 29th days of the trial. Because patients defaulted, these examinations did not always take place. In fact, twelve ( 4.5 per cent.) of the patients failed to return after the initial visit. A further 39 (14.7 per cent.) defaulted within 2 weeks and another eight ( 3 per cent.) disappeared before their follow-up was completed (Tables III and V). All patients who defaulted were asymptomatic at the time of their default. 165 (62 per cent.) completed the 4 weeks' surveillance, compared with 109 (45.2 per cent.) in the previous trial.

Patients were asked to hold their urine for at least 2 and preferably $4 \mathrm{hrs}$ before examination. Smears and cultures were taken when there was evident discharge. In patients considered cured of their urethritis, the urine in the 2-glass test became clear and remained so throughout the period of observation.

\section{SIDE-EFFECTS}

The only side-effects noted were of a gastrointestinal nature. These occurred in five (1.9 per cent.) of the 266 treated. Four patients vomited within 10 minutes of taking the syrup and one other had severe diarrhoea later. Treatment failed in all who vomited.

\section{GONORRHOEA}

Non-specific urethritis developed in eight (5.6 per cent.) of the 144 patients and these, together with the five who failed to return after treatment, were excluded from the trial, leaving 131 patients who were followed-up. (Table III).

Gonorrhoea persisted in the two patients who vomited and recurred in another twelve after treatment with Vibramycin syrup. In each case the diagnosis was confirmed by culture and full antibiograms were obtained.

From these investigations and the histories it was concluded that five of the 131 patients ( 3.8 per cent.) were probably re-infected (Table IV). All admitted to further sexual intercourse before the recurrence of gonorrhoea and in some cases the initial and subsequent antibiograms were significantly different.

Nine (6.9 per cent.) of the patients did not respond to treatment. They denied re-exposure to risk of infection and were classified as treatment failures. There was very little difference between the initial and subsequent antibiograms. The full period of surveillance was completed by 93 (64.6 per cent.) patients who were clinically cured at that time.

\section{NON-SPECIFIC URETHRITIS}

Of the 122 patients treated, 72 (59 per cent.) completed the 4 weeks' surveillance satisfactorily. Seven patients failed to re-attend after treatment and two acquired gonorrhoea in the week after treatment. Of the remaining 113 followed, non-specific urethritis

TABLE III Results-uncomplicated gonorrhoea

\begin{tabular}{|c|c|c|c|c|c|c|}
\hline \multirow[b]{2}{*}{ Day no. } & \multirow[b]{2}{*}{$\begin{array}{l}\text { No. on } \\
\text { surveillance }\end{array}$} & \multirow{2}{*}{$\begin{array}{l}\text { Last attendance } \\
\text { before withdrawal } \\
\text { from trial }\end{array}$} & \multicolumn{4}{|c|}{ Reason for withdrawal from trial } \\
\hline & & & $\begin{array}{l}\text { Subsequent } \\
\text { default }\end{array}$ & $\begin{array}{l}\text { Post-treatment } \\
\text { NSU }\end{array}$ & Re-infection & $\begin{array}{l}\text { Treatment } \\
\text { failure }\end{array}$ \\
\hline $\begin{array}{l}1 \\
2 \\
4 / 5 \\
8 \\
15 \\
22 \\
29\end{array}$ & $\begin{array}{r}144 \\
139 \\
124 \\
115 \\
102 \\
95 \\
93\end{array}$ & $\begin{array}{r}5 \\
15 \\
9 \\
13 \\
7 \\
2 \\
93\end{array}$ & $\begin{array}{r}5 \\
13 \\
3 \\
5 \\
1 \\
2\end{array}$ & $\begin{array}{l}2 \\
3 \\
3\end{array}$ & $\begin{array}{l}2 \\
3\end{array}$ & $\begin{array}{l}2^{\mathrm{a}} \\
4 \\
3\end{array}$ \\
\hline Total & & 144 & 29 & 8 & 5 & 9 \\
\hline
\end{tabular}

aVomited within 10 minutes 
TABLE IV Gonococcal infection persisting or recurring after treatment

\begin{tabular}{|c|c|c|c|c|c|c|c|}
\hline \multirow{2}{*}{$\begin{array}{l}\text { Marital } \\
\text { status }\end{array}$} & \multirow{2}{*}{$\begin{array}{l}\text { Age } \\
\text { (yrs) }\end{array}$} & \multirow{2}{*}{ Promiscuous } & \multicolumn{2}{|c|}{ Antibiogram } & \multirow{2}{*}{$\begin{array}{l}\text { Admitted } \\
\text { re-exposure }\end{array}$} & \multirow{2}{*}{$\begin{array}{l}\text { Day of } \\
\text { surveillance }\end{array}$} & \multirow[b]{2}{*}{ Classification } \\
\hline & & & Initial & Post-treatment & & & \\
\hline $\begin{array}{l}\text { Single } \\
\text { Married } \\
\text { Single } \\
\text { Separated } \\
\text { Married }\end{array}$ & $\begin{array}{l}27 \\
27 \\
23 \\
27 \\
41\end{array}$ & $\begin{array}{l}\text { Yes } \\
\text { Yes } \\
\text { Yes } \\
\text { Yes } \\
\text { Yes }\end{array}$ & $\begin{array}{l}0.3^{\mathrm{b} c} \\
0.6^{\mathrm{b} c} \\
0.06 \\
0.06 \\
0.03\end{array}$ & $\begin{array}{l}0 \cdot 3^{\mathrm{b}} \\
0 \cdot 12^{\mathrm{b}} \\
0 \cdot 6^{\mathrm{b}} \mathrm{c} \\
0 \cdot 3^{\mathrm{b}} \\
0 \cdot 6^{\mathrm{b}} \mathrm{c}\end{array}$ & $\begin{array}{l}\text { Yes } \\
\text { Yes } \\
\text { Yes } \\
\text { Yes } \\
\text { Yes }\end{array}$ & $\begin{array}{r}8 \\
8 \\
15 \\
15 \\
15\end{array}$ & Re-infection \\
\hline $\begin{array}{l}\text { Married } \\
\text { Married } \\
\text { Single } \\
\text { Single } \\
\text { Single } \\
\text { Married } \\
\text { Single } \\
\text { Married } \\
\text { Single }\end{array}$ & $\begin{array}{l}29 \\
29 \\
28 \\
35 \\
22 \\
59 \\
37 \\
24 \\
34\end{array}$ & $\begin{array}{l}\text { Yes } \\
\text { Yes } \\
\text { Yes } \\
\text { Yes } \\
\text { Yes } \\
\text { No } \\
\text { Yes } \\
\text { Yes } \\
\text { Yes }\end{array}$ & $\begin{array}{l}0.03 \\
0.06 \\
0.06 \\
1 \cdot 2^{\mathrm{b} c} \\
1 \cdot 2^{\mathrm{b}} \mathrm{c} \\
0.3^{\mathrm{b}} \\
0.3^{\mathrm{b}} \\
0.6^{\mathrm{b}} \\
0.3^{\mathrm{b}}\end{array}$ & $\begin{array}{l}0.03 \\
0.06 \\
0.06 \\
1 \cdot 2^{\mathrm{b} c} \\
1 \cdot 2^{\mathrm{b}} \mathrm{c} \\
0.3^{\mathrm{b}} \\
0.3^{\mathrm{b}} \\
0.6^{\mathrm{b}} \\
0.6^{\mathrm{b}} \mathrm{c}\end{array}$ & $\begin{array}{l}\text { No } \\
\text { No } \\
\text { No } \\
\text { No } \\
\text { No } \\
\text { No } \\
\text { No } \\
\text { No } \\
\text { No }\end{array}$ & $\begin{array}{l}2^{\mathrm{a}} \\
2^{\mathrm{a}} \\
4 \\
4 \\
4 \\
5 \\
6 \\
8 \\
8\end{array}$ & Treatment failure \\
\hline
\end{tabular}

a Patients vomited within 10 minutes of taking syrup

${ }^{b}$ Resistant to streptomycin

'Resistant to sulphafurazole

TABLE $\mathrm{V}$ Results in cases of non-specific urethritts

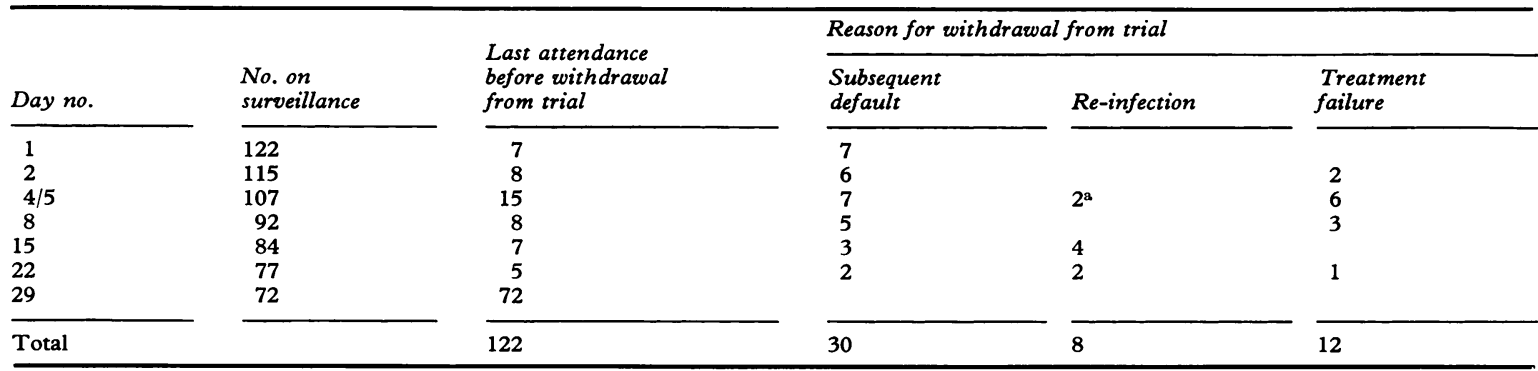

${ }^{\mathrm{a} G o n o r r h o e a}$

persisted in two men who vomited within 10 minutes of taking the syrup and recurred in a further sixteen patients (Table V).
In six ( 5.3 per cent.), relapsing urethritis was considered to be due to re-infection (Table VI). All these patients admitted to re-exposure and the urethritis,

TABLE VI Urethritis persisting or recurring after treatment (initial diagnosis non-specific urethritis)

\begin{tabular}{|c|c|c|c|c|c|}
\hline Marital status & Age (yrs) & Promiscuous & Admitted re-exposure & Day of surveillance & Classification \\
\hline $\begin{array}{l}\text { Single } \\
\text { Married } \\
\text { Single } \\
\text { Single } \\
\text { Single } \\
\text { Single }\end{array}$ & $\begin{array}{l}27 \\
27 \\
25 \\
22 \\
23 \\
23\end{array}$ & $\begin{array}{l}\text { Yes } \\
\text { Yes } \\
\text { Yes } \\
\text { Yes } \\
\text { Yes } \\
\text { Yes }\end{array}$ & $\begin{array}{l}\text { Yes } \\
\text { Yes } \\
\text { Yes } \\
\text { Yes } \\
\text { Yes } \\
\text { Yes }\end{array}$ & $\begin{array}{l}15 \\
15 \\
15 \\
15 \\
22 \\
22\end{array}$ & Re-infection \\
\hline $\begin{array}{l}\text { Single } \\
\text { Single } \\
\text { Single } \\
\text { Separated } \\
\text { Married } \\
\text { Married } \\
\text { Married } \\
\text { Single } \\
\text { Single } \\
\text { Single } \\
\text { Married } \\
\text { Married }\end{array}$ & $\begin{array}{l}20 \\
31 \\
32 \\
32 \\
35 \\
36 \\
36 \\
23 \\
22 \\
18 \\
44 \\
28\end{array}$ & $\begin{array}{l}\text { No } \\
\text { No } \\
\text { No } \\
\text { Yes } \\
\text { No } \\
\text { Yes } \\
\text { No } \\
\text { Yes } \\
\text { Yes } \\
\text { No } \\
\text { No } \\
\text { No }\end{array}$ & $\begin{array}{l}\text { No } \\
\text { No } \\
\text { No } \\
\text { No } \\
\text { No } \\
\text { No } \\
\text { No } \\
\text { No } \\
\text { No } \\
\text { No } \\
\text { No } \\
\text { No }\end{array}$ & $\begin{array}{c}2^{\mathrm{a}} \\
2^{\mathrm{a}} \\
5 \\
5 \\
5 \\
5 \\
5 \\
5 \\
8 \\
8 \\
8 \\
22^{\mathrm{b}}\end{array}$ & Treatment failure \\
\hline
\end{tabular}

apatients vomited within 10 minutes of taking syrup

'Sub-group A Chlamydia isolated after a subsequent relapse 
which resolved initially, did not recur until more than 10 days after treatment. To date, these two points seem to be our best criteria for re-infection. The twelve (10.6 per cent. of the 113 followed) other patients with persistent or recurrent urethritis denied re-exposure and, whether or not alcohol had been consumed, were considered to be treatment failures. The symptoms recurred within a week of treatment in all but one case; subgroup A Chlamydia was eventually cultured from this patient's urethra following a subsequent relapse.

\section{Discussion}

The results of the two trials of Vibramycin are probably comparable as the trial criteria were the same. Certainly, as far as gonorrhoea is concerned, the sensitivities of the strains of $N$. gonorrhoeae to the various antibacterial agents were similar, although there was an interval of two years between the trials.

Table VII summarizes the differences between the use of Vibramycin capsules and syrup in the treatment of uncomplicated urethritis in men. The higher failure rates of the syrup in the treatment of gonorrhoea and non-specific urethritis fail to attain any statistical significance, nor does the higher rate of post-gonococcal non-specific urethritis associated with the capsules. The marked difference was in the low rate of side-effects when the syrup was used, this being highly significant statistically $\left(\chi^{2}=12.8\right.$; $n=1 ; \mathrm{P}<0.001)$.

TABLE VII Comparison between Vibramycin capsules and syrup in the treatment of urethritis in males

\begin{tabular}{|c|c|c|}
\hline Dose & $\begin{array}{l}3 \text { capsules } \\
(300 \text { mg. })\end{array}$ & $\begin{array}{l}30 \mathrm{ml} . \text { syrup } \\
(300 \mathrm{mg} .)\end{array}$ \\
\hline $\begin{array}{l}\text { Known failure rates } \\
\text { (per cent.) } \\
\text { Gonorrhoea } \\
\text { Non-specific urethritis }\end{array}$ & $\begin{array}{l}6 \cdot 4 \\
6 \cdot 7\end{array}$ & $\begin{array}{r}6.9 \\
10 \cdot 6\end{array}$ \\
\hline $\begin{array}{l}\text { Post-gonococcal non-specific } \\
\text { urethritis (per cent.) }\end{array}$ & $7 \cdot 5$ & $5 \cdot 6$ \\
\hline Side-effects (per cent.) & $\begin{array}{l}15.4 \text { (with or without } \\
\text { an anti-emetic) } \\
3.5 \text { (with milk) }\end{array}$ & $\begin{array}{l}1.9 \text { (the drug } \\
\text { alone) }\end{array}$ \\
\hline
\end{tabular}

Other workers, Gray, Phillips, and Nicol (1970) in the United Kingdom, Baytch and Rankin (1972) in Australia, and Mutchnick (1972) in the United States of America, obtained less satisfactory results using doxycycline $\mathrm{HCl}$ capsules in the same dosage in the treatment of gonorrhoea. However, in none of these series was a note made of the sensitivity to the various antibacterial agents of the strains of $N$. gonorrhoeae. It may well be that the incidence of resistant strains varies from one part of the world to another and, even in one country, from one town to another. It is therefore difficult to compare the results of one series with another, unless all use the same criteria, and even then there may be other factors which cause differences in the results.

In the Glasgow area, nine out of every ten men suffering from non-specific urethritis are apparently cured by a single dose of $300 \mathrm{mg}$. doxycycline $\mathrm{HCl}$. As yet, it is not possible to assess the incidence of chlamydial infections, but it may well be that less sensitive strains of that organism are responsible for the failures noted. In due course, it will be possible to assess the incidence not only of chlamydial infections in the area, but also of the various strains of that organism.

In the initial trial using capsules, gastrointestinal side-effects were troublesome, and these still tended to occur even when anti-emetics or milk were taken with the capsules. When the syrup was used, no additional medication was necessary and side-effects were minimal.

All the patients found doxycycline syrup palatable, even in amounts as large as $30 \mathrm{ml}$. Unexpected difficulties arose with some patients who refused to believe that treatment could be so easy or pleasant, insisting that they had been given 'a refreshment' and that their condition was being neglected.

At the moment, doxycycline syrup lies in the higher price range of our therapeutic armamentarium, but it deserves consideration particularly for the needle-shy, apprehensive patient who is also a legal minor. It is insufficiently appreciated in certain quarters that the cheapest drug available is not necessarily the most economical in the end. Cost accounting must take into consideration not only the price of further therapy, but also the time spent by the medical, nursing, and social staff in tracing, diagnosing, and treating any additional consorts if the initial treatment has failed.

The drug of choice is therefore the one which gives the most rapid, efficient, and predictable results; doxycycline $\mathrm{HCl}$, in a single dose of $300 \mathrm{mg}$., either as capsules or syrup, merits careful consideration whenever oral treatment is being contemplated for urethritis in men.

\section{Summary}

144 male patients suffering from gonococcal urethritis and 122 patients suffering from non-specific urethritis were treated with a single oral dose of $300 \mathrm{mg}$. doxycycline $\mathrm{HCl}$ syrup (Vibramycin). 
The failure rate was 6.9 per cent. in the 131 cases of uncomplicated gonorrhoea and 10.6 per cent. in the 113 cases of non-specific urethritis which were followed-up. Doxycycline $\mathrm{HCl}$ failed to prevent the development of non-specific urethritis in 5.6 per cent. of the patients treated for gonorrhoea.

Side-effects were infrequent ( 1.9 per cent.) and the preparation was acceptable to the patients. It is reasonably effective in both gonorrhoea and nonspecific urethritis in men and should be considered whenever oral treatment is deemed appropriate.

\section{References}

BAYTCH, H., and RANKIN, D. W. (1972) Brit. F. vener. Dis., 48, 129

Gray, R. C. F., Phillips, I., and Nicol, C. S. (1970) Ibid., 46, 401

MAsterton, G., and Schofield, C. B. S. (1972) Ibid., 48, 121

MoffetT, M., McGill, M. I., Masterton, G., and SCHOFIELD, C. B. S. (1972) Ibid., 48, 126
MutchNick, M. G. (1972) Ibid., 48, 381

Sylvestre, L., and Gallai, Z. (1968) Un. méd. Canad., 97, 639

Le sirop de chlorydrate de Doxycycline (Vibramycine) en dose buccale unique dans le traitement des urétrites masculines non compliquées

\section{SOMMAIRE}

144 hommes atteints d'urétrite gonococcique et 122 atteints d'urétrite non spécifique furent traités par une dose buccale unique de $\mathbf{3 0 0} \mathrm{mg}$ de sirop d'HCl de Doxycycline (Vibramycine).

Le taux d'échec fut de 6,9 pour cent pour les 131 cas degonococcie non compliquée et de 10,6 pour cent pour les 113 cas d'urétrite non spécifique qui furent suivis. L'HCl de Doxycycline n'a pas empêché une urétrite non spécifique chez 5,6 pour cent des malades traités pour gonococcie.

Les effets secondaires furent rares (1,9 sur cent) et la préparation bien acceptée par les malades; elle est raisonnablement efficace à la fois pour la gonococcie et l'urétrite non spécifique chez les hommes et doit être prise en considération chaque fois qu'un traitement buccal semble approprié. 